УДК 34

\title{
ВОПРОСЫ ОБ ОБЖАЛОВАНИИ ЗАОЧНОГО РЕШЕНИЯ В УСЛОВИЯХ ОБНОВЛЁННОГО ГРАЖДАНСКО- ПРОЦЕССУАЛЬНОГО ЗАКОНОДАТЕЛЬСТВА
}

\section{Квартальнова Виктория Викторовна студент} Лошкарев Андрей Викторович доцент

ФГБОУ ВО «Самарский государственный экономический университет»

\begin{abstract}
Аннотация: Представленная работа посвящена ряду вопросов, связанных с обжалованием заочного решения в условиях обновлённого гражданскопроцессуального законодательства. Освящены наиболее важные проблемные моменты, связанные с осуществлением ответчиком своего права обжаловать решения заочного производства, а также приведен пример судебной практики по обсуждаемым вопросам. Указаны перспективы развития законодательных норм, регулирующих порядок обжалования.
\end{abstract}

Ключевые слова: заочное производство, судебное решение, отзыв, апелляционная инстанция, ответчик, неявка.

\section{QUESTIONS ABOUT APPEALING A DECISION IN ABSENTIA IN THE CONTEXT OF THE UPDATED CIVIL PROCEDURE LEGISLATION}

\section{Kvartalnova Victoria Viktorovna Loshkarev Andrey Viktorovich}

\begin{abstract}
The presented work is devoted to a number of issues related to the appeal of a decision in absentia in the context of updated civil procedure legislation. The article highlights the most important issues related to the defendant's right to appeal against decisions of absentee proceedings, as well as provides examples of judicial practice on the issues under discussion. The prospects for the development of legislative norms regulating the appeal procedure are indicated.
\end{abstract}

Key words: in absentia proceedings, a judicial decision, opinion, the appellate court, the defendant, failure to appear. 


\section{НАУКА, ОБЩЕСТВО, КУЛЬТУРА: ПРОБЛЕМЫ И ПЕРСПЕКТИВЫ ВЗАИМОДЕЙСТВИЯ В СОВРЕМЕННОМ МИРЕ}

На сегодняшний день одной из актуальных проблем гражданского судопроизводства является неявка в суд ответчика по каким-либо причинам. Отсутствие ответчика составляет некоторые препятствия как для истца, так и непосредственно для суда. В связи с этим, на законодательном уровне был закреплён институт заочного производства. Законодатель преследует цель соблюдения баланса интересов каждой стороны, принимающей участие в гражданском судопроизводстве.

В случае, если ответчик не согласен с вынесенным решением, то законодатель предоставляет ему право оспорить несправедливое на его взгляд решение двумя способами. Однако, стоит отметить, что закон не устанавливает чётких различий между ними и не выделяет оптимальные условия, подходящие под конкретное дело, что является проблемным аспектом не только для ответчика, оказавшегося в непростой ситуации, но и существенно затрудняет разрешение спорных моментов правоприменительной практики.

Итак, существует два способа обжаловать заочное судебное решение: обратиться с апелляционной жалобой в вышестоящий суд, данным правом могут воспользоваться все лица, участвующие в деле или же обратиться в суд первой инстанции, вынесший заочное решение, с заявлением о пересмотре постановления этим же судом, в данном случае обратиться может лишь ответчик, сославшись на то, что суд не в полной мере исследовал доказательства по делу или же не принял во внимание конкретные события, которые могли бы повлиять на иной исход дела.

Между указанными способами существует ряд существенных отличий. Начнём с того, что обращаясь в вышестоящую инстанцию лицо просит отметить принятое заочное решение, поскольку оно по его мнению незаконно и необоснованно, а также лицо полагает, что судом допущены ошибки при применении норм материального и процессуального права [2]. Второй способ представляет собой «отзыв заочного решения». При этом, ответчик просит суд предоставить ему возможность доказать свою правоту в новом заседании, используя один из главных принципов судопроизводства - состязательность.

Обжалование заочного решения суда первой инстанции можно считать одним из самых сложный процессуальных институтов, потому что он охватывает сразу два самостоятельных процессуальных действия: подачу заявления об отмене заочного правоприменительного акта, а также непосредственно обращение с апелляционной жалобой. Нормы гражданскопроцессуального кодекса, на наш взгляд выстроены таким образом, что 


\section{НАУКА, ОБЩЕСТВО, КУЛЬТУРА: ПРОБЛЕМЫ И ПЕРСПЕКТИВЫ ВЗАИМОДЕЙСТВИЯ В СОВРЕМЕННОМ МИРЕ}

ответчику довольно сложно понять, какой способ оспаривания заочного решения будет более простым и доступным. Законодатель не совсем точно указывает соотношение права на подачу заявления об отмене заочного решения и право на обращение в вышестоящий суд. Невзирая на явные различия двух способов оспаривания, а также их независимость и самостоятельность, сложно определить тот факт, что у ответчика имеется выбор между двумя самостоятельными процедурами. Согласно ч. 1 ст.237 ГПК РФ ответчик может использовать упрощённый способ обжалования, который содержит в себе два взаимоприемлемых этапа. Первый этап- ответчик в течении семи дней, со дня получения копии документа, подаёт заявление об отмене вынесенного решения. Если суд принял данную жалобу, то ответчик может воспользоваться, имеющимся у него правом доказать суду, что первый судебный акт был вынесен неправомерно [3]. Если же суд отказывает, выдаёт отрицательный ответ на жалобу, то ответчик переходит ко второму способу «отзыва» заочного судебного решения, а именно, подаёт жалобу на апелляционное рассмотрение. Ч.2 ст. 237 указывает на то, что ответчик имеет возможность обжалования решение суда первой инстанции в апелляционном порядке в течении одного месяца со дня вынесения определения суда об отказе в удовлетворении заявления об отмене заочного решения суда [3]. Сложность в понимании перечисленных норм состоит в том, что невнятно изложена позиция законодателя. С одной стороны он говорит о том, что у ответчика есть два варианта обжалования первоначального решения, с другой стороны, указывает на то, что оба способа вытекают друг из друга и существование одного невозможно без существования второго.

Ещё одним проблемным аспектом является отсутствие конкретного перечня условий подачи апелляционной жалобы на заочное решение суда первой инстанции. В данном случае используется общий порядок подачи апелляционной жалобы в гражданском судопроизводстве. Напомним, что подать апелляционную жалобу на заочное решение суда может не только ответчик, но и истец, однако об участии иных лиц ничего не говорится. По сути, прокурор, который имеет возможность подавать жалобу со стороны истца, в данном случае ограничен в реализации видимого права. Не упоминание прокурора может выражаться как, запрет на участие прокурора путём принесения представлений по делам, рассмотренным в рамках заочного производства, либо как явное противоречие норм гражданско-процессуального законодательства, регулирующих порядок пересмотра решений в 


\section{НАУКА, ОБЩЕСТВО, КУЛЬТУРА: ПРОБЛЕМЫ И ПЕРСПЕКТИВЫ ВЗАИМОДЕЙСТВИЯ В СОВРЕМЕННОМ МИРЕ}

апелляционной инстанции. Предполагается, что прокурор имеет возможность принесения апелляционной представлений по делам заочного производства, если он участвовал в них лично [4].

Исходя из вышеизложенного, можно судить о том, что существует немало пробелов и коллизий в той части гражданско-процессуального законодательства, которая регулирует порядок и способы обжалования заочного решения суда первой инстанции. Подобное противоречие норм и их невнятное изложение порождают всевозможные проблемные нюансы. Ещё одним немало важным нюансом являются сроки обжалования заочного решения. Как правило, именно этот нюанс вызывает массу вопросов. Обращаясь к ст. 321 ГПК РФ определим общее правило обжалования апелляционной жалобы. Жалоба подаётся в течении одного месяца на не вступившие в законную силу решения со дня его принятия судом в окончательной форме. А ч.2 ст.237 указывает на день вручения или направления ответчику копии судебного акта [3]. Традиционно под окончательной формой судебного решения понимается не момент объявления решения в зале судебного заседания, а изготовление его полного текста.

В отношении заочного решения законодатель предпринял иную меру определяющую сроки обжалования. Течение месячного срока на апелляционное обжалование, берёт начало с совершенно другой даты, противоречащей общему положению законодательства. Течение срока начинается по окончании истечения семидневного срока, который был предоставлен ответчику для урегулирования вопроса подачи заявления об отмене первоначального решения. И если ответчик воспользовался казанным правом, то он получает возможность подать апелляционную жалобу в течении месяца со дня вынесения определения об отказе в удовлетворении заявления об отмене заочного решения. Всё это свидетельствует о большом количестве временных затрат на ведение судопроизводства.

Приведём пример конкретного дела, из судебной практике по делам об обжаловании заочного решения суда первой инстанции.

Управление пенсионного фонда обратилось в суд с иском к Градзион А.Н. о взыскании некой суммы денежных средств. Ответчик не явилась на судебное заседание, не уведомила суд о уважительных причинах её неявки, а также не подала ходатайство о возражении проведения судебного заседания без её присутствия. Суд, на основании представленных истцом доказательств принял решение о взыскании всей суммы с ответчика. После 


\section{НАУКА, ОБЩЕСТВО, КУЛЬТУРА: ПРОБЛЕМЫ И ПЕРСПЕКТИВЫ ВЗАИМОДЕЙСТВИЯ В СОВРЕМЕННОМ МИРЕ}

вынесения судебного решения, ответчику была направлена копия судебного акта. Суд также пояснил, что в случае непринятия ответчиком данного решения, она может подать заявление об отмене и пересмотре заочного решения, судом вынесшим его, а также, подать апелляционную жалобу в случае отказа суда в удовлетворении заявления. Ответчик использовала данное право [5].

В юридической практике содержится немало примеров обжалования заочного решения суда, все они сопровождаются массой вопросов о сущности проведения подобной процедуры.

В завершении представленной работы, стоит сказать, что устранение обсуждаемых проблем и вопросов возможно, путём систематизации норм, гражданского законодательства, отвечающих за обжалование заочных решений. На наш взгляд, законодатель должен чётко установить конкретные требования к обжалованию, выделив заочное ведение дела.

Развитие института заочного производства является перспективным шагом на пути цивилизованного общества, так как ежедневно возникает множество обстоятельств, по которым ответчик не может явиться на судебное разбирательство, а у иных лиц, принимающих участие в деле, могут возникать вопросы, требующие повторного внимания и разрешения.

Способы обжалования вынесенного заочного решения также оставляют множество вопросов, которые достаточно сложно разобрать людям, не знающим смысл и содержания норм законодательства. Преодолеть данный правовой пробел можно с помощью более углублённого толкования норм гражданско-процессуального законодательства.

В целом, институт заочного производства находится в процессе своего развития, ежедневно разрешая уникальные дела и спорные моменты. В связи с этим стоит ожидать в ближайшее время устранения пробелов и коллизий в законодательстве, а также упрощение, его положений, для дальнейшего их понимания и использования сторонами.

\section{Список литературы}

1. Черных И.И. «К вопросу об обжаловании заочного решения в условиях обновленного гражданского процессуального законодательства». // Режим доступа URL: https://justicemaker.ru/view-article.php?id=3\&art=3582.

2. "Гражданский процессуальный кодекс Российской Федерации" от 14.11.2002 N 138-Ф3 (ред. от 31.07.2020) //СПС// «КонсультантПлюс». Ст. 233235; 237-238; 240 ГПК РФ. (Дата обращения 30.11.20). 
3. Комментарий к Статье 237 ГПК РФ. // Режим доступа URL: http://gpkodeksrf.ru/rzd-2/podrzd-2/gl-22/st-237-gpk-rf.

4. Приказ Генпрокуратуры России от 11.01.2021 N 2 "Об обеспечении участия прокуроров в гражданском и административном судопроизводстве" // Режим доступа URL: https://legalacts.ru/doc/prikaz-genprokuratury-rossii-ot11012021-n-2-ob-obespechenii/.

5. Решение № 2-4045/2020 2-4045/2020 M-1267/2020 M-1267/2020 от 29 мая 2020 г. по делу № 2-4045/2020 // Режим доступа URL: https://sudact.ru/ regular/doc/r9wKuXJz1Udq/. 